\title{
Faktor-faktor Risiko Stres Kerja pada Aparatur Sipil Negara
}

\author{
Bryan Reppi $^{1}$, Oksfriani Jufri Sumampouw ${ }^{1}$, Hesty Lestari ${ }^{2}$ \\ ${ }^{1 .}$ Program Pascasarjana Ilmu Kesehatan Masyarakat Universitas Sam Ratulangi \\ ${ }^{2}$ Fakultas Kedokteran Universitas Sam Ratulangi \\ E-mail: bryanreppiayent@gmail.com
}

\begin{abstract}
Background: The Health and Safety Executive (HSE) stated that stress and depression related to work in 2017/2018 were 595,000 cases with a prevalence rate of 1,800 per 100,000 workers. Work-related stress and depression also contribute 44\% of all cases of occupational health disorders and 57\% of absences from work due to illness. Job stress can occur to workers in all fields including government employees. This study aims to determine the relationship between risk factorsand work-related stress on civil servants in Regional Financial and Asset Agency of North Sulawesi Province. Method: This research was a quantitative study with cross sectional research design, conducted in 2019, from August to September at the Regional Finance and Assets Agency (BKAD) of North Sulawesi Province. The sample was 118 people determined by the Total Sampling method. Data was collected by respondent completing NIOSH Generic Job Stress Questionnaire. Univariate, bivariate, and multivariate were use to analyze the data using SPSS program. Results: The results showed that there was a relationship between interpersonal conflict, workload, social support and work stress on civil servants in BKAD North Sulawesi Province. Conclusion: This study concluded that interpersonal conflict is the most influential factor in work-related stress on civil servants in BKAD North Sulawesi Province. It is recommended for all civil servants in BKAD North Sulawesi Province to be more aware to the work-related stress factors so that it can be controlled
\end{abstract}

Keywords: work-related stress, civil servant, North Sulawesi

\section{PENDAHULUAN}

Survei yang dilakukan oleh Health and Safety Executive (HSE) menyatakan bahwa stres dan depresi terkait pekerjaan pada tahun 2017/2018 adalah 595.000 kasus dengan tingkat prevalensi 1.800 per 100.000 pekerja. Stres dan depresi karena pekerjaan juga menyumbangkan $44 \%$ dari semua kasus gangguan kesehatan karena pekerjaan dan 57\% dari ketidakhadiran di kantor karena sakit (HSE, 2018) Stres kerja dapat terjadi pada pekerja di semua bidang termasuk juga pada pegawai pemerintahan. Penelitian yang dilakukan Parslow (2004) pada pegawai pemerintah Australia menunjukkan bahwa stres pada pegawai pemerintah wanita meningkat disebabkan oleh jam kerja dan kontrol terhadap pekerjaan sedangkan pada pegawai pemerintah pria disebabkan oleh ketidakmampuan dalam melakukan pekerjaan. Penelitian yang sering dilakukan lebih memfokuskan pada bidang industri, sementara itu dengan mempertimbangkan kemungkinan terjadinya stres pada bidang lain seperti pemerintahan maka perlu 
dilakukan juga penelitian di bidang pemerintahan. Survei yang dilakukan HSE pada pekerja di Great Britain menyatakan bahwa stres karena pekerjaan lazim terjadi di bidang layanan publik seperti administrasi publik (HSE, 2018).

Gambaran stres kerja pada pegawai pemerintahan di Indonesia ditunjukkan dalam penelitian yang dilakukan oleh Widiantini dkk (2014) tentang Stres kerja PNS di Lingkungan Sekretariat Jendral Kementerian Kesehatan Republik Indonesia. Penelitian ini menunjukkan bahwa 6,5\% mengalami stres ringan, 33,5\% mengalami stress sedang dan 60\% mengalami stres berat. Penelitian juga dilakukan Laelasari dkk (2015) pada PNS di Badan Litbang Kesehatan Kementerian Kesehatan RI. Penelitian ini menunjukkan bahwa beban kerja dan gaya manajemen merupakan faktor yang berpengaruh terhadap stres kerja pada pegawai fungsional umum dan fungsional peneliti.

Penelitian tentang stres kerja pada Aparatur Sipil Negara (ASN) juga dilakukan oleh Sorongan dkk (2018) dengan judul Hubungan Antara Stres Kerja Dan Upah Dengan Produktivitas Kerja Pada Pegawai di Dinas Kesehatan Kota Manado. Hasil penelitian menunjukkan bahwa $27,7 \%$ pegawai mengalami stres kerja rendah dan $72,3 \%$ pegawai mengalami stres kerja sedang. Penelitian ini menunjukkan bahwa Aparatur Sipil Negara juga berpotensi mengalami stres kerja yang disebabkan oleh berbagai faktor dalam pekerjaan. Hurrel dkk (1988) menyatakan stres kerja disebabkan oleh empat faktor utama, yaitu faktor kondisi pekerjaan, faktor individu, faktor diluar pekerjaan serta faktor pendukung.

Peraturan Menteri Tenaga Kerja No. 01/MEN/1979 tentang Pelayanan Kesehatan Kerja menyatakan bahwa salah satu tujuan pelayanan kesehatan kerja adalah meningkatkan kesehatan badan, kondisi mental, dan kemampuan fisik tenaga kerja. Hal ini menunjukkan bahwa kondisi mental atau psikologi pekerja harus di awasi karena salah satu penyebab penyakit akibat kerja adalah stres. Stres yang dialami seseorang akan mengubah cara kerja sistem kekebalan tubuh. Stres akan menurunkan daya tahan tubuh terhadap serangan penyakit (Dajtmiko, 2016). Dalam situasi kerja, stres sebagai indikasi dinamika seseorang yang sedang berupaya melakukan perubahan lingkungan kerja untuk mencapai keinginannya (Wahyudi, 2017)

Penelitian ini dilakukan di Badan Keuangan dan Aset Daerah Provinsi Sulawesi Utara yang merupakan salah satu instansi pemerintahan di Provinsi Sulawesi Utara dengan tugas utama yaitu membantu Gubernur menyelenggarakan pengelolaan keuangan dan aset daerah. Peraturan Gubernur No. 34 Tahun 2018 tentang Kedudukuan, Susunan Organisasi, Tugas dan Fungsi, serta Tata Kerja BKAD Sulut Bab II Pasal 5 menyatakan bahwa Badan Pengelola Keuangan dan Aset Daerah Provinsi merupakan Badan Pengelola Keuangan dan Aset Daerah Provinsi Tipe A untuk mewadahi pelaksanaan fungsi Badan Daerah Provinsi dengan beban kerja yang besar. Beban kerja berlebih merupakan pembangkit stres. Beban kerja berlebih dapat berupa beban kerja kuantitatif dan kualitatif (Munandar, 2014). Salah satu alasan peneliti memilih lokasi penelitian di BKAD Provinsi Sulawesi Utara adalah karena menurut peneliti BKAD Provinsi Sulawesi Utara adalah salah satu instansi pemerintahan yang mempunyai beban kerja yang besar sesuai dengan uraian tugas dan fungsi dari instansi ini. Selain itu berdasarkan hasil wawancara, sering kali ASN harus kerja hingga larut malam atau hingga pagi untuk menyelesaikan pekerjaan. Tujuan penelitian ini yaitu untuk mengetahui faktor-faktor risiko stres kerja yang terjadi pada ASN di Badan Keuangan dan Aset Daerah Provinsi Sulawesi Utara.

\section{METODE PENELITIAN}

Penelitian ini merupakan penelitian dengan menggunakan rancangan cross sectional. Jumlah responden adalah 110 orang dengan status sebagai Aparatur Sipil 
Negara. Variabel bebas dalam penelitian ini yaitukonflik interpersonal, beban kerja dan dukungan sosial dan variabel terikat yaitu stres kerja. Data dianalisis dalam univariat, bivariat, dan multivariat. Uji bivariat menggunakan korelasi spearman dan korelasi pearson untuk mengetahui hubungan antara variabel bebas dengan variabel terikat. Variabel konflik interpersonal yang datanya tidak terdistribusi normal menggunakan uji korelasi spearman. Variabel beban kerja dan dukungan sosial yang datanya terdistribusi normal menggunakan uji korelasi pearson. Uji regresi logistik digunakan untuk mengetahui variabel mana yang paling berpengaruh terhadap stres kerja.

\section{HASIL DAN PEMBAHASAN}

\section{Analisis Univariat}

Analisis univariat menjelaskan tentang sebaran karakteristik responden berdasarkan umur, jenis kelamin, tingkat pendidikan dan status pernikahan. Karakteristik responden dapat dilihat pada Tabel 1.

Tabel 1. Distribusi responden menurut karakteristik

\begin{tabular}{lcc}
\hline Karakteristik Responden & $\mathrm{n}$ & $\%$ \\
\hline Umur & 1 & 0,9 \\
17-25 Tahun & 25 & 22,7 \\
26-35 Tahun & 37 & 33,6 \\
36-45 Tahun & 33 & 30 \\
46-55 Tahun & 14 & 12,7 \\
55-65 Tahun & & \\
Jenis Kelamin & 40 & 36,4 \\
Laki-laki & 70 & 63,6 \\
Perempuan & & \\
Tingkat Pendidikan & 25 & 22,7 \\
SMA & 7 & 6,4 \\
Diploma III & 73 & 66,4 \\
Diploma IV/Sarjana & 5 & 4,5 \\
Magister & & 3,6 \\
Status Pernikahan & 4 & 96,4 \\
Belum Menikah & 106 & \\
Sudah Menikah & 5 . &
\end{tabular}

Hasil penelitian menunjukkan bahwa sebagian besar umur responden adalah kelompok umur 36-45 tahun yaitu sebanyak 33,6\%, sedangkan yang paling sedikit adalah kelompok umur 17-25 tahun yaitu sebanyak 0,9\%. Responden yang berpartisipasi dalam penelitian ini yaitu $63,6 \%$ laki-laki dan $36,4 \%$ perempuan. Pendidikan terakhir dari sebagian besar responden yaitu Diploma IV/Sarjana sebanyak $66,4 \%$. Status pernikahan dari mayoritas responden adalah sudah menikah yaitu sebanyak $96,4 \%$ responden.

Hasil penelitian menunjukkan bahwa sebagian besar umur responden adalah kelompok umur 36-45 tahun yaitu sebanyak 33,6\%, sedangkan yang paling sedikit adalah kelompok umur 17-25 tahun yaitu sebanyak 0,9\%. Responden yang berpartisipasi dalam penelitian ini yaitu $63,6 \%$ laki-laki dan $36,4 \%$ perempuan. Pendidikan terakhir dari sebagian besar responden yaitu Diploma IV/Sarjana sebanyak $66,4 \%$. Status pernikahan dari mayoritas responden adalah sudah menikah yaitu sebanyak $96,4 \%$ responden. 
Tabel 2. Distribusi responden menurut faktor-faktor risiko stres kerja

\begin{tabular}{lcc}
\hline Karakteristik Responden & $\mathrm{N}$ & \% \\
\hline Lingkungan Fisik & & \\
Kurang Baik & 46 & 43,6 \\
Baik & 62 & 56,4 \\
Konflik Peran & 53 & 48,2 \\
Tinggi & 57 & 51,8 \\
Rendah & & \\
Konflik Interpersonal & 62 & 56,4 \\
Tinggi & 48 & 43,6 \\
Rendah & 101 & 91,8 \\
Beban Kerja & 9 & 8,2 \\
Tinggi & & \\
Rendah & 108 & 98,2 \\
Dukungan Sosial & 2 & 1,8 \\
Baik & & \\
Kurang Baik & 45 & 40,9 \\
Stres Kerja & 65 & 59,1 \\
Tinggi & &
\end{tabular}

Selanjutnya, dilakukan analisis bivariat menggunakan uji Spearman. Hasilnya dapat dilihat pada Tabel 3.

Tabel 3. Hasil uji Spearman hubungan antara faktor resiko dan stres kerja

\begin{tabular}{lcc}
\hline \multicolumn{1}{c}{ Variabel } & $\rho$ & $r$ \\
\hline Konflik Interpersonal & 0.028 & 0.210 \\
Beban Kerja & 0.031 & 0.206 \\
Dukungan Sosial & 0.005 & -0.267 \\
\hline
\end{tabular}

Salah satu tujuan dari penelitian ini adalah untuk mengetahui apakah terdapat hubungan antara konflik interpersonal dengan stres kerja pada ASN di BKAD Provinsi Sulawesi Utara. Menurut P. W. Cummings konflik diartikan sebagai suatu proses interaksi sosial dimana dua orang atau lebih, atau dua kelompok atau lebih, berbeda atau bertentangan dalam pendapat atau tujuan mereka (Wahyudi, 2017). Dalam penelitian ini 56,4\% mengalami konflik dengan kategori tinggi. Hasil uji bivariat dengan uji korelasi spearman menyatakan bahwa terdapat hubungan antara konflik interpersonal dengan stress kerja $(\rho=0.028)$. Hubungan tergolong lemah $(\mathrm{r}=0.210)$ dengan arah korelasi positif yang artinya semakin tinggi konflik peran maka akan meningkatkan stres kerja pada pekerja. Hasil penelitian ini sesuai dengan teori yang dikemukakan oleh Munandar (2014) bahwa stres kerja dapat timbul karena tenaga kerja harus bekerja sama dengan tenaga kerja lain yang berkepribadian kasar atau tidak memiliki kepekaan dalam berinteraksi sosial sehingga dapat menyebabkan terjadi konflik antar individu.

Penelitian yang dilakukan oleh Lestari dkk (2017) tentang Pengaruh Konflik Interpersonal dan Beban Kerja terhadap Stres Kerja Karyawan PT. Pos Indonesia (Persero) Pusat Denpasar menunjukkan hasil serupa dengan penelitian yang dilakukan oleh penulis. Hasil penelitiannya yaitu konflik interpersonal berpengaruh positif dan signifikan terhadap stres kerja.

Berdasarkan hasil penelitian terdapat $91,8 \%$ yang mengalami kategori beban kerja tinggi. Beban kerja berlebih dapat menjadi salah satu faktor pembangkit stres. Hasil tabulasi silang menunjukkan dari $91,8 \%$ yang mengalami beban kerja tinggi terdapat $40 \%$ yang mengalami stres kerja. Hal ini dikarenakan terkadang jumlah pekerjaan yang diberikan sudah melebihi kemampuan dari pekerja (Munandar, 2014). Pekerjaan yang 
melebihi kapasitas atau potensi diri pekerja menyebabkan mudah lelah dan bekerja dalam ketegangan tinggi (Anies, 2014). Hasil uji korelasi Pearson menunjukkan bahwa terdapat hubungan antara beban kerja dengan stres kerja $(\rho=0.031)$. Hubungan tergolong lemah dengan arah korelasi positif yang artinya semakin tinggi beban kerja dari pekerja akan meningkatkan stres kerja yang dialami pekerja. Hal ini sejalan dengan penelitian yang dilakukan oleh Habibi dkk (2018) tentang Analisis Faktor Resiko Stres Kerja pada Pekerja di Unit Produksi PT. Borneo Melintang Buana Export. Hasilnya yaitu terdapat hubungan antara beban kerja dengan stres kerja.

Hasil analisis uji pearson menunjukkan terdapat hubungan antara dukungan sosial dengan stres kerja pada ASN di BKAD Provinsi Sulawesi Utara $(\rho=0.005)$. Hal ini sejalan dengan penelitian yang dilakukan oleh Setiawan dkk (2013) pada Pegawai UPT Pengelolaan Sumberdaya Air Bengawan Solo Bojonegoro. Hasil penelitian menunjukkan terdapat hubungan antara dukungan sosial terhadap stres kerja karyawan.

Dukungan sosial yang diukur pada penelitian ini adalah dukungan terhadap pekerjaan yang dirasakan oleh responden dan bisa berasal dari atasan, rekan kerja, pasangan, teman, dan keluarga. Dukungan sosial dapat berupa bantuan dalam kesulitan pekerjaan, diskusi mengenai pekerjaan, hingga masalah pribadi dari responden yang kemungkinan besar dapat berpengaruh terhadap responden. Arah korelasi dalam hubungan antara dukungan sosial dan stres kerja adalah negatif $(r=-0,267)$ yang artinya semakin banyak dukungan yang diterima oleh responden terkait perkerjaannya maka akan mengurangi stres yang dialami oleh responden terkait pekerjaan. Hal ini dikarenakan dukungan yang diterima responden kemungkinan besar akan membuat responden fokus dan nyaman dalam bekerja. Penelitian lain dengan hasil yang sejalan juga dilakukan oleh Lady dkk (2017) tentang Analisis tingkat stres kerja dan faktorfaktor penyebab stres kerja pada pegawai BPBD Kota Cilegon. Hasilnya adalah terdapat hubungan antara dukungan sosial dengan stres kerja, semakin tinggi dukungan yang didapat oleh pekerja terkait dengan pekerjaannya maka akan mengurangi tingkat stres yang dialami.

Tabel 4. Hasil uji multivariat faktor yang paling dominan terhadap stres kerja

\begin{tabular}{lcc}
\hline \multicolumn{1}{c}{ Variabel } & Sig. & OR \\
\hline Konflik Interpersonal & 0.028 & 2.484 \\
Beban Kerja & 0.075 & 7.554 \\
Dukungan Sosial & 0.476 & 0.258 \\
\hline
\end{tabular}

Berdasarkan tabel di atas dapat disimpulkan bahwa variabel yang paling dominan adalah konflik interpersonal $(\rho=0.028)$. Konflik interpersonal yang tinggi beresiko sebanyak dua kali menyebabkan stres kerja tinggi dibandingkan dengan konflik interpersonal rendah. Berdasarkan hasil tabulasi nilai stres kerja didapatkan hasil yaitu 61 orang atau 55,5\% mengalami stres kerja tinggi dan 49 orang atau 45,5\% orang mengalami stres kerja rendah. Untuk mengetahui variabel apa yang paling berhubungan maka dilakukan analisis multivariat dengan uji regresi logistik. Hasil uji multivariat yang sudah dilakukan menunjukkan bahwa faktor yang paling berpengaruh terhadap stres kerja adalah variabel konflik interpersonal dengan nilai signifikansi $\rho=0.028$ dan nilai $\mathrm{OR}=2.484$. Hal ini berarti dari semua responden yang mengalami stres kerja dengan kategori tinggi sebagian besar dikarenakan oleh faktor konflik interpersonal. Sering terjadinya konflik dalam dalam hubungan rekan kerja akan menyebabkan ketidaknyamanan dalam pekerjaan yang dapat menjadi pembangkit stres.

Penelitian yang dilakukan oleh Sihombing (2019) tentang Faktor-faktor yang mempengaruhi stres kerja pada karyawan PT. Perkebunan Nusantara IV Kabupaten Simalungun Sumatera Utara menyatakan hasil yang berbeda. Faktor yang paling dominan menurut penelitian ini adalah faktor konflik peran. Perbedaan ini disebabkan 
oleh beberapa hal yaitu, yang pertama metode yang digunakan dan variabel yang diukur berbeda. Kemudian bidang objek penelitian juga berbeda yaitu pemerintahan dan industri perkebunan. Konflik peran yang terjadi di industri perkebunan kemungkinan dikarenakan adanya perintah atau arahan dari pimpinan perusahaan yang tidak sesuai dengan tugas yang harus dilakukan oleh pekerja. Sedangkan yang terjadi di BKAD Provinsi Sulawesi Utara kemungkinan besar karena adanya hubungan kerja yang tidak baik antara pekerja. Hubungan kerja yang tidak baik ini akan menyebabkan timbulnya stres kerja.

\section{PENUTUP}

Kesimpulan penelitian ini yaitu Terdapat hubungan antara konflik interpersonal, beban kerja dan dukungan sosial dengan dengan stres kerja. Variabel konflik interpersonal dan beban kerja menunjukkan hubungan yang tergolong lemah dengan arah korelasi positif sedangkan variabel dukungan sosial menunjukkan hubungan yang tergolong lemah dengan arah korelasi negatif. Variabel yang paling dominan berpengaruh terhadap stres kerja adalah konflik interpersonal. Berdasarkan hasil penelitian ini maka disarankan pada seluruh ASN di BKAD Provinsi Sulawesi Utara agar lebih memahami faktor-faktor yang menyebabkan stres kerja terhadap diri masingmasing sehingga dapat dilakukan pengendalian terhadap stres kerja yang di alami.

\section{DAFTAR PUSTAKA}

Anies, P. 2014. Kedokteran Okupasi. Ar-ruz Media. Yogyakarta

Habibi, J. 2018. Analisis Faktor Stres Kerja pada Pekerja di Unit Produksi PT. Borneo Melintang Buana Export. Jurnal of Nursing and Public Health. Vol. 6 No.2 Oktober 2018 https://jurnal.unived.ac.id/index.php/jnph/article/download/658/569/

Health Safety Executive (HSE). 2018. Work Related Stress Depression or Anxiety Statistics in Great Britain, 2018. (Online) http://www.hse.gov.uk/statistics/causdis/stress.pdf

Hurrel, J. 1988. Exposure to job stress - A new psychometric instrument.Scandinavian Journal of Work, Environment \& Health. (Online) www.ncbi.nlm.nih.gov/pubmed/3393871

Lady, L. 2017. Analisis Tingkat Stres Kerja dan Faktor-Faktor Penyebab Stres Kerja pada Pegawai BPBD Kota Cilegon. Jurnal Industrial Services Vol. 3 No. 1b (Online) jurnal.untirta.ac.id/index.php/jiss/article/download/2084/1617

Laelasari, E. 2016. Faktor Kondisi Pekerjaan yang Mempengaruhi Stress Kerja Pada Pegawai Negeri Sipil di Badan Litbang Kesehatan, Kementerian Kesehatan. Jurnal Ekologi Kesehatan Vol. 15 No 2.

Lestari, N. 2017. Pengaruh Konflik Interpersonal dan Beban Kerja terhadap Stres Kerja Karyawan PT. Pos Indonesia (Persero) Pusat Denpasar. E-Jurnal Manajemen UNUD Vol. VI. No. 12

Munandar, A. 2014. Psikologi Industri dan Organisasi. Penerbit Universitas Indonesia. Jakarta

Parslow, R. 2004. The impact of employee level and work stress on mental health and GP service use: an analysis of a sample of Australian government Employees. BMC Public Health. (Online) http://www.biomedcentral.com/1471-2458/4/41

Setiawan, A. 2013. Pengaruh Dukungan Sosial terhadap Stres Kerja pada Karyawan. Jurnal Mahasiswa Psikologi Vol.1 No. 3 Tahun 2013

Sihombing, I, K. 2019. Faktor-faktor yang Mempengaruhi Stres Kerja Karyawan PT. Perkebunan Nusantara IV Kebun Tobasari Kabupaten Simalungun Sumatera 
Utara. Jurnal Discovery Vol. $04 \quad$ No. $01 \quad$ (Online) http://ejournal.unhasy.ac.id/index.php/discovery/article/view/388

Wahyudi. 2017. Manajemen Konflik dan Stres dalam Organisasi. Penerbit Alfabeta. Bandung

Widiantini, W. 2014. Aktivitas Fisik, Stres, dan Obesitas pada Pegawai Negeri Sipil. Jurnal Kesehatan Masyarakat Nasional Vol. 8, No. 7. (Online) http://journal.fkm.ui.ac.id/kesmas/article/view/374 